\title{
Trace Metal Contents in the Leaves of Cassia occidentalis Linn from Some Selected Sites in Katsina, Nigeria.
}

\author{
Fatima Binta Suleiman
}

\begin{abstract}
Representative samples of Cassia occidentalis were randomly collected from three selected sites in Katsina and Batagarawa local government areas of Katsina state. The samples were prepared using standard procedures. The concentrations of chromium, copper, nickel, cobalt, iron, manganese, zinc, and lead were determined using atomic absorption spectroscopy(AAS) after ashing the samples in a muffle furnace at $550^{\circ} \mathrm{C}$ for 4 hours. The percentage moisture content was found to be $77.98 \%, 71.08 \%$, and $75.45 \%$ in the samples collected from sites $A, B$ and $C$ respectively. The concentration of chromium ranged from $0.714 \pm 0.01$ to $1.429 \pm 0.01 \mathrm{mg} / \mathrm{kg}$, copper $(1.25 \pm 0.01$ to $3.75 \pm 0.04 \mathrm{mg} / \mathrm{kg})$, nickel $(1.190 \pm 0.02$ to $4.762 \pm 0.03 \mathrm{mg} / \mathrm{kg})$, cobalt $(4.032 \pm 0.04$ to $7.258 \pm 0.06 \mathrm{mg} / \mathrm{kg})$, iron $(10.417 \pm 0.37$ to $41.667 \pm 6.07 \mathrm{mg} / \mathrm{kg})$, manganese $(0.926 \pm 0.16$ to $1.852 \pm 0.65 \mathrm{mg} / \mathrm{kg})$, zinc $(7.955 \pm 1.28$ to $15.909 \pm 3.12 \mathrm{mg} / \mathrm{kg})$ and lead from $0.127 \pm 0.02$ to $0.131 \pm 0.01 \mathrm{mg} / \mathrm{kg}$. All the values with the exception of nickel in site $B$ and iron in site A were below the maximum permissible limit for medicinal plants. ANOVA indicated no significant difference P>0.05 in the concentration of metals in the different sites studied. It was concluded that the concentration of heavy metals in medicinal plants should be regularly monitored and checked before use for medication.
\end{abstract}

\section{Introduction}

Cassia occidentalis is an herb or subshrub which is about one meter high and branched. Its leaves are compound, composite and paripinnate with 5-8 pairs of usually oval leaflets. It is mainly used as worm expeller, to treat chicken pox and convulsion in children (Mann et al., 2003). It is also used in the treatment of malaria and typhoid fever. The term heavy metals refer to any metallic chemical element that has relatively high density and is toxic or poisonous at low concentrations (Ikejemba and Sakpa, 2014). Examples include chromium (Cr), copper $(\mathrm{Cu})$, nickel $(\mathrm{Ni})$, cobalt $(\mathrm{Co})$, iron $(\mathrm{Fe})$, manganese $(\mathrm{Mn})$, and zinc $(\mathrm{Zn})$. Plants contain trace heavy metals in various concentrations whose accumulation is different from plant to plant of the same location. Environment also has profound effect on the heavy metals accumulation contents in plants (Niaz et al., 2013).

Metals such as cobalt, chromium, copper, iron, manganese and zinc are classified as nutritionally essential. Others such as boron, nickel and silicon are classified as metals with possible benefits, while cadmium, lead, mercury, silver etc, are metals with no known benefits (Lokeshappa et al., 2012).

Above the recommended dose even the nutritionally essential metals may be dangerous because they tend to bioaccumulate in tissues of living organisms although as trace elements, some are essential to maintain the metabolism of the human body. Increasing attention has focused on heavy metal concentrations of vegetables all over the world because of their important possible and negative roles in human life (Ozturk et al., 2011).

In this study the levels of $\mathrm{Cr}, \mathrm{Cu}, \mathrm{Pb}, \mathrm{Ni}, \mathrm{Co}, \mathrm{Fe}, \mathrm{Mn}$ and $\mathrm{Zn}$ in the leaves of Cassia occidentalis from three selected sites in Katsina state were determined.

\section{Sample Collection}

Representative plant samples were randomly collected from three sites in Katsina and Batagarawa local governments of Katsina state. Site A is within a residential area in Katsina metropolis, site B is around a low activity area in Batagarawa local government and site $\mathrm{C}$ is within a densely populated school also in. Batagarawa local government. Six replicate samples were collected in each sampling location within an area of $4 \mathrm{~m}^{2}$. The samples were mixed to form a composite and transported in labeled brown envelopes to the laboratory where they were identified by a botanist.

\section{Sample preparation}

The samples were gently washed under running tap water and rinsed with distilled water before air drying. They were then oven dried in an oven (Genlab model MINO/100/F) at $105^{\circ} \mathrm{C}$ to constant mass.

The dried samples were ground using a laboratory blender model no. 8010ES, sieved with a $2 \mathrm{~mm}$ mesh sieve and stored in an air tight container prior to analysis. 


\section{Moisture Content}

Three crucibles labeled A, B and $\mathrm{C}$ were washed and dried to constant weight in an oven at $105^{\circ} \mathrm{C}$. They were separately weighed after cooling in a dessicator and the weight recorded. $10 \mathrm{~g}$ each of samples A, B and $\mathrm{C}$ were placed in the labeled crucibles. Each crucible containing the samples was weighed and the weight recorded. They were then placed in an oven at $105^{\circ} \mathrm{C}$ and dried to constant weight. Each was weighed after cooling in a dessicator. The percentage moisture content was calculated using the formula

$$
\mathrm{M}_{\mathrm{n}}=\frac{\mathrm{W}_{\underline{\mathrm{w}}}-\underline{\mathrm{W}}_{\mathrm{d}}}{\mathrm{W}_{\mathrm{w}}} \times 100
$$

Where, $\mathbf{M}_{\mathrm{n}}=$ percentage moisture content of the samples.

$\mathrm{W}_{\mathrm{w}}=$ Weight of the sample before drying.

$\mathrm{W}_{\mathrm{d}}=$ Weight of the sample after drying.

\section{Sample treatment}

$1 \mathrm{~g}$ of the leave samples was weighed into a porcelain crucible and a few drops of $2 \mathrm{M}$ nitric acid was added to it to aid ashing. They were placed in a muffle furnace (model LF3, S.No. F286207) and the temperature gradually increased to $550^{\circ} \mathrm{C}$. It was left to ash at $550^{\circ} \mathrm{C}$ for four hours. The ash samples were allowed to cool and $10 \mathrm{~cm}^{3}$ of $2 \mathrm{M}$ nitric acid was added to it. The ash suspension was filtered into a $25 \mathrm{~cm}^{3}$ volumetric flask using whatman filter paper no. 41 and the solution made up to the mark with deionised water (Bempah et al., 2012). Calibration curves were obtained from the concentrations of standard stock solutions prepared by dissolving appropriate amounts of metal salts in 6M nitric acid. Fresh working solutions were obtained by serial dilution of the stock solutions. Reagent blank determinations were used to correct the instrument readings. Readings were taken in triplicates using Atomic Absorption Spectrophotometer (Buck Scientific Model 210).

\section{Statistical Analysis}

The mean and standard deviations of the data were calculated. ANOVA was used to compare metal concentrations in the three sampling sites

\section{Moisture Content}

\section{Results}

Percentage moisture content was found to be $77.98 \%, 71.08 \%$ and $75.45 \%$ in the samples collected from sites A, B and C respectively. Water is a significant component of biological materials. Excess water in herbal materials encourages microbial growth, the presence of fungi or insects and deterioration following hydrolysis (WHO, 2005). Drying methods can lower the water activity to the level required for preventing growth of Aspergillus species and also for ensuring quality of medicinal herbs which may get destroyed upon over drying (Araujo and Bauab, 2012).

Table 1: Heavy metal contents in the leaves of Cassia occidentalis in the three sampling sites.

\begin{tabular}{|c|c|c|c|c|c|c|c|c|}
\hline & $\mathrm{Cr}$ & $\mathrm{Cu}$ & $\mathrm{Ni}$ & $\mathrm{Co}$ & $\mathrm{Fe}$ & $\mathrm{Mn}$ & $\mathrm{Zn}$ & $\mathrm{Pb}$ \\
\hline & $\mathrm{mg} / \mathrm{kg}$ & $\mathrm{mg} / \mathrm{kg}$ & $\mathrm{mg} / \mathrm{kg}$ & $\mathrm{mg} / \mathrm{kg}$ & $\mathrm{mg} / \mathrm{kg}$ & $\mathrm{mg} / \mathrm{kg}$ & $\mathrm{mg} / \mathrm{kg}$ & $\mathrm{mg} / \mathrm{kg}$ \\
\hline $\mathrm{A}$ & $0.714 \pm 0.01$ & $3.75 \pm 0.04$ & $3.571 \pm 0.02$ & $4.032 \pm 0.04$ & $41.667 \pm 6.07$ & $1.852 \pm 0.65$ & $7.955 \pm 1.28$ & $0.130 \pm 0.02$ \\
\hline $\mathrm{B}$ & $1.429 \pm 0.01$ & $1.25 \pm 0.01$ & $1.190 \pm 0.02$ & $7.258 \pm 0.06$ & $10.417 \pm 0.37$ & $0.926 \pm 0.16$ & $15.909 \pm 3.12$ & $0.131 \pm 0.01$ \\
\hline $\mathrm{C}$ & $0.714 \pm 0.01$ & $2.500 \pm 0.02$ & $4.762 \pm 0.03$ & $4.839 \pm 0.03$ & $12.500 \pm 0.28$ & $1.852 \pm 0.65$ & $11.364 \pm 0.42$ & $0.127 \pm 0.02$ \\
\hline
\end{tabular}

\section{Discussion}

Table 1 shows the concentration of metals in the leaves of Cassia occidentalis in the three sampling sites. There were visible variations in the concentrations of metals in the different sites although ANOVA indicated no significant difference $(\mathrm{p}>0.05)$ in the concentration of metals in the different sites at $95 \%$ confidence level.

\section{Chromium}

The mean concentrations of chromium were $0.714 \pm 0.01$ in sites $\mathrm{A}$ and $\mathrm{C}$, and $1.429 \pm 0.01$ in site $\mathrm{B}$. The relatively low concentration of $\mathrm{Cr}$ compared to other metals may be explained by its low solubility in soil water thereby leading to low plant uptake ( Lenntech, 2012). The high level in site B may be because the area is rocky 
and chromium occur naturally rocks, soils and gases. All the values were below the recommended value of $1.5 \mathrm{mg} / \mathrm{kg}$. In addition to insulin, $\mathrm{Cr}$ is responsible for reducing blood glucose levels, and is used to control certain cases of diabetes (Lancashire, 2012). Ingestion of 1-5g of chromate results in severe acute effects such as gastrointestinal disorders, haemorrhagic diathesis, convulsions and death from cardiovascular shocks (WHO, 1996). Other negative health effects include allergic and asthmatic reactions, diarrhea, stomach and intestinal bleedings, cramps, liver and kidney damage (Lenntech, 2012; Khan et al., 2008). It is a dietary requirement for a number of organisms and the human body contains approximately $0.03 \mathrm{ppm}$ of chromium (Lenntech, 2012).

\section{Copper}

The concentration of copper varied from $3.75 \pm 0.04 \mathrm{mg} / \mathrm{kg}$ in site A, $1.25 \pm 0.01 \mathrm{mg} / \mathrm{kg}$ in site B and $2.50 \pm 0.02 \mathrm{mg} / \mathrm{kg}$ in site C. Copper is a nutritionally essential metal (Lokeshappa et al., 2012). But its critical doses can cause anaemia, acne, adrenal hyperactivity and insufficiency, allergies, hair loss, cancer, depression, diabetes etc. (Lokeshappa et al., 2012). The values obtained in this study are lower than the $10 \mathrm{mg} / \mathrm{kg}$ recommended value. Niaz et al., (2013) found copper concentrations in plant parts ranging from 3.14$21.40 \mathrm{mg} / \mathrm{kg}$ while Maobe et al., (2012) had values between $0.305-1.44 \mathrm{ppm}$.

\section{Nickel}

The highest concentration of $4.762 \pm 0.03 \mathrm{mg} / \mathrm{kg}$ was obtained in site C, followed by $3.571 \pm 0.02 \mathrm{mg} / \mathrm{kg}$ in site A and $1.190 \pm 0.02 \mathrm{mg} / \mathrm{kg}$ in site B. The United State environmental protection Agency permissible limit for nickel in medicinal plants is $1.5 \mathrm{mg} / \mathrm{kg}$ (Niaz et al., 2013), while Jabeen et al.,(2010), reported the permissible limit by FAO/WHO in edible plants as $1.63 \mathrm{ppm}$. Based on the above, the only value within the permissible limit is that of site $\mathrm{B}$ which is a bushy area with relatively low human activity when compared to the other two sites.

Nickel is a dietary requirement for many organisms, but may be toxic in large doses (Lenntech, 2012). It is known to be responsible for oral and intestinal cancer, depression, heart attack, haemorrhages, kidney dysfunction, low blood pressure, skin problems, nausea and vomitting (Lokeshappa et al., 2012) although it is required in minute quantity in the pancrease for the production of insulin (Khan et al., 2008). Niaz et al., (2013) obtained values ranging from 0.81 to $14.11 \mathrm{mg} / \mathrm{kg}$ in the plants they studied, Maobe et al., (2012), had values ranging from $0.589-1.60 \mathrm{ppm}$ while Baranowski et al., (2012) obtained $0.74 \pm 0.08$ to $4.63 \pm 0.53 \mathrm{mg} / \mathrm{kg}$ in the herb samples they studied.

\section{Cobalt}

The highest concentration of $7.258 \pm 0.06 \mathrm{mg} / \mathrm{kg}$ was recorded in site $\mathrm{B}$, followed by $4.839 \pm 0.03 \mathrm{mg} / \mathrm{kg}$ in site $\mathrm{C}$ and $4.032 \pm 0.04 \mathrm{mg} / \mathrm{kg}$ in site A. Cobalt is a trace element required for a variety of biological processes which is used as a component of vitamins B-12 (Kulhari et al., 2013). Maobe et al. (2012) obtained values ranging from 0.967 to $6.067 \mathrm{ppm}$ in their study.

\section{Iron}

The average values of iron changed from $10.417 \pm 0.37 \mathrm{mg} / \mathrm{kg}$ in site $\mathrm{B}$ to $12.50 \pm 0.28 \mathrm{mg} / \mathrm{kg}$ in site $\mathrm{C}$ and $41.667 \pm 6.07 \mathrm{mg} / \mathrm{kg}$ in site A. The concentration in site A is much above the $20 \mathrm{mg} / \mathrm{kg}$ WHO recommended level of iron in medicinal plants. This could be because there is a dumpsite around the area where materials containing iron are dumped. The high amount could also be due to foliar absorption from the surrounding air. Iron is an important trace element and iron-protein mixtures play a vital role in all living organisms (Kulhari et al., 2013), being an essential component of haemoglobin and also facilitates the oxidation of carbohydrates protein and fat to control body weight which is an important factor in diabetes (Khan et al., 2005).

Green plants apply iron for energy transformation processes so, plants growing in soils with little iron may experience growth problems (Lenntech, 2012). However, iron overdose has been the leading cause of death by toxicological agents in children younger than 6 years of age (Kulhari et al., 2013). Signs of gastro-intestinal toxicity are shown after ingestion of more than $20 \mathrm{mg} / \mathrm{kg}$ iron( Kulhari et al., 2013). Khan et al.(2008) obtained values ranging from 33.21-206.69ppm in the different plants they studied while Maobe et al. (2012) obtained values ranging from 0.967 to $6.067 \mathrm{ppm}$. Iron has been found to occur in high concentrations in Nigeria soils (Fagbote and Olanipekum, 2010; Adefemi et al., 2007) which may be an explanation for the relatively high values obtained.

\section{Manganese}

Site B had the lowest manganese concentration with a value of $0.926 \pm 0.16 \mathrm{mg} / \mathrm{kg}$, while sites A and C had $1.852 \pm 0.65 \mathrm{mg} / \mathrm{kg}$ each. All the values are below the WHO maximum permissible limit of $200 \mathrm{mg} / \mathrm{kg}$ in medicinal plants. It is an essential trace element for all forms of life and adverse health effects can be caused by 
Trace Metal Contents in the Leaves of Cassia Occidentalis Linn from Some Selected Sites in .....

inadequate intake (WHO,1996). It is a trace element which acts as a cofactor for many enzymes (Kulhari et al.,2013), whose deficiency in plants causes chlorosis (Khan et al., 2008) and the estimated safe and adequate daily dietary intake in adults is $11 \mathrm{mg}$ /day (Khan et al., 2008; Niaz et al., 2013). Excess intake can lead to neurological disorder (SON, 2009) and is primarily regulated because of the aesthetic problems associated with elevated levels which can distrupt the nervous system and regeneration of haemoglobin. Niaz et al., (2013) obtained values ranging from $4.42-21.03 \mathrm{mg} / \mathrm{kg}$ while Khan et al., (2008) got values from $1.39 \pm 0.06$ to $52.94 \pm 0.01 \mathrm{mg} / \mathrm{kg}$ in the different plant materials they studied.

Zinc

Site A had the lowest concentration of zinc with a value of $7.955 \pm 1.28 \mathrm{mg} / \mathrm{kg}$, followed by site $\mathrm{C}$ with a mean concentration of $11.364 \pm 0.42 \mathrm{mg} / \mathrm{kg}$ and the highest concentration was in site B with a value of $15.909 \pm 3.12 \mathrm{mg} / \mathrm{kg}$. All the values are below the $50 \mathrm{mg} / \mathrm{kg}$ WHO maximum permissible limit in medicinal plant (Niaz et al., 2013). Zinc is a dietary mineral for humans and animals but overdoses may negatively influence human and animal health (Lenntech, 2012). It is an essential trace element and plays an important role in various cell processes including normal growth, brain development, behavioural response, bone formation and wound healing (Maobe et al., 2012).

Nausea, vomitting, diarrhea, bleeding and abdominal cramps are associated with overdosage (WHO, 1996). Baranowski et al.,(2012) obtained values ranging from $10.34 \pm 0.82$ to $285.20 \pm 6.10 \mathrm{mg} / \mathrm{kg}$ in the samples of herbs they studied while Maobe et al.,(2012) obtained values in the range 0.736 to $1.833 \mathrm{ppm}$.

\section{Lead}

The concentration of lead was found to be $0.130 \pm 0.02 \mathrm{mg} / \mathrm{kg}, 0.131 \pm 0.01 \mathrm{mg} / \mathrm{kg}$ and $0.127 \pm 0.02 \mathrm{mg} / \mathrm{kg}$ in sites $\mathrm{A}, \mathrm{B}$, and $\mathrm{C}$ respectively. The values were below the $10 \mathrm{mg} / \mathrm{kg}$ WHO permissible limit. Lead is highly hazardous for plants, animals and micro organisms. Continuous consumption of fertilizers, fuel combustion and sewage sludge are major reasons leading to escalation in lead pollution (Kulhari et al.,2013). Maobe et al., (2012) obtained values ranging from 0.148 to $0.407 \mathrm{ppm}$ of lead in the medicinal plants they studied while Baranowski et al., 2002 obtained values in the range $4.12 \pm 0.12$ to $73.56 \pm 8.72 \mathrm{mg} / \mathrm{kg}$. Lead causes both acute and chronic poisoning and poses adverse effects on kidneys, liver, vascular and immune system (Maobe et al,2012). Other typical symptoms of lead poisoning include anaemia, headache, convulsions, and central nervous system disorder (Khan et al., 2008). Lead enters the body system through air, water and food (Lokeshappa et al.,2012).

\section{Conclusion}

It was found that the amount of heavy metals are different in the same plant taken from different locations although ANOVA indicated no significant difference in the concentrations obtained at $95 \%$ confidence level. Continuous monitoring of the concentrations of heavy metals in medicinal plants in different locations should be encouraged. It is also important that the concentration of heavy metals should be checked before the leaves and other plant parts are used for pharmaceutical purposes and local human consumption as net accumulation can be detrimental to health.

\section{References}

[1]. Adefemi, OS,Olaofe, O. and Asaulo, S.S.(2007). Seasonal Variation of heavy Metal Distribution in sediment of major Dams in Ekiti State. Pakistan Journal of Nutrition. 6(6); 705-707.

[2]. Araujo, M G.F. and Bauab, T.M.(2012). Microbial Quality of Medicinal Plant Materials. Latest Research in Quality control. Intech open: 67-8 Available http://dx.doi.org/10.5772/51072.

[3]. Baranowska, I., Srogi, K., Wlochowice, A., Szczepanik. (2002).Determination of Heavy Metal Contents in Samples of Medicinal Herbs. Polish Journal of Environmental Studies. 11 (5): 467-471.

[4]. Bempah, C.K., Boateng, J., Asomaning, J., Asabere, S.B. (2012). Heavy Metals Contamination in Herbal plants from some Ghanaian Markets. Journal of Microbiology, Biotechnology and food Sciences:2(3): 886 - 896

[5]. Fagbote, E.O. and Olanipekun, E.O. (2010). Speciation of Heavy Metals in Sediment of Agbabu Bitumen Deposit Area, Nigeria. Journal of Applied Science and Environmental Management. 14(4): 47-51.

[6]. Ikejimba, C.C. and Sapka, S. (2014). Comparative Study of some Heavy Metals Concentrations in Water and Tympanotonus fuscatus var radula Samples of Egbokodo River,Warri, Nigeria. International Journal of modern Biological Research. 2:7-15.

[7]. Jabeen, S., Shall, M.T. Khan, S. and Hayat, M.Q (2010). Determination of major and Trace Elements in Ten Important falk therapentic plants of Hanpur Basin. Pakistan Journal of medicinal plants Research. 4(7) : 559-566.

[8]. Khan S. A., Khan, L. Hussain, I., Marwat, K.B., Akhtar, N. (2008). Profile of Heavy metals in Selected Medicinal Plants. Pakistan Journal of weed Science Research. 14(1-2): $101-110$.

[9]. Kulhari, A., Sheorayan, A., Bajar, S. Sarkar S., Chaudhury, A. and Kalia, R. K. (2013). Investigation of Heavy Metals in Frequently Utilized Medicinal Plants Collected from Environmentally Diverse Locations of North western India. Springer plus. 2: 676 available http: //www. Springer plus.com.

[10]. Lenntech, B. V. (2012). Heavy metals. Available, http: //www. Lenntech .com.pt/processes/pesadol- heavy-metals.htm

[11]. Lokeshappa, B., Shivpuri, K., Tripathi,V., Dikshit, A.K. (2012). Assessment of Toxic Metals in Agricultural Produce. Food and public Health. 2(1): 24-29. Available at http:// Journal. Sapub.org/fph. 
[12]. Mann, A.,Gbate, M., and Umar, A. N. (2003). Medicinal and Economic plants of Nupeland. Jube Evans Books and Publications, Niger State, Nigeria.

[13]. Maobe, M.A.G., Gatebe, E., Gitu, L. and Rotich, H. (2012). Profile of Heavy metals in Selected Medicinal Plants used for the Treatment of Diabetes, Malaria and Pneumonia in Kisii Region, South west Kenya. Global Journal of pharmacology. 6(3): 245251.

[14]. Niaz, A., Ullah, N., Rehman, A., Ahmed, I., Ikhlag, M. and Rehman, H.U. (2013). Pollution Based study of Heavy metals in some Selected Medicinal Plants by Dry Digestion Method. International Journal of pharma Sciences and Research. 4(2): 17-24.

[15]. Ozturk, E., Atsan, E., Polat, T. and Kara, K. (2011). Variation of Heavy metals Concentration of Potato (Solanum tuberosum L.) Cultivars. The Journal of Animal and Plant Sciences. 21(2): 235-239.

[16]. Standard Organisation of Nigeria, SON. (2007). Nigeria Standard for Drinking Water Quality. Nigeria Industry Standard.

[17]. World Health Organisation, WHO (1996). International Programme on Chemical Safety.Guidelines for Drinking Water Quality. $2^{\text {nd }}$ edition, Volume 2. Health Criteria and other supporting information. WHO, Geneva.

[18]. World Health Organisation WHO (2005) Quality Control methods for medicinal plant materials revised, Geneva. 